\title{
Orbital Metastases as the First Manifestation of Lung Adenocarcinoma
}

\author{
Paul Zarogoulidis ${ }^{a}$ Eirini Terzi ${ }^{a}$ Georgios Kouliatsis ${ }^{a}$ \\ Sofia Androudi ${ }^{b}$ Theodoros Kontakiotis ${ }^{\mathrm{a}}$ \\ Thomas Zaramboucas ${ }^{c}$ Kostas Zarogoulidis ${ }^{a}$ \\ aPulmonary Clinic of Aristotle University of Thessaloniki, ${ }^{b}$ Ophthalmology \\ Institute of Thessaloniki, and cPathology Department of Aristotle University of \\ Thessaloniki, Thessaloniki, Greece
}

\section{Key Words}

Lung cancer · Orbital metastasis · Adenocarcinoma - Anti-VEGF

\begin{abstract}
Reduction in visual acuity due to orbital metastasis is rarely the first sign of lung cancer and very few cases have been published in the literature. Here we report a rare case of lung adenocarcinoma with orbital metastasis as the first presenting sign. The incidence of primary tumors that metastasize to the orbit is approximately $7 \%$. In $19 \%$ of the cases, there is no history of cancer when the patient presents with ophthalmic symptoms, and in $10 \%$, the primary site remains obscure despite intensive systemic evaluation. Our patient showed a partial improvement in vision after successful combination of chemotherapy and radiotherapy. Blurred vision due to orbital metastasis as the primary symptom of lung cancer is very uncommon. A great index of suspicion is essential when an orbital lesion appears.
\end{abstract}

\section{Case Presentation}

A 38-year-old Caucasian woman, who was a heavy smoker, was referred to the ophthalmology clinic with reduced vision, blurred and double vision, persistent pain in the right frontal-parietal region, and increased pressure on the right orbit for the past 2 months. She had no nausea, weight loss, vomiting, or respiratory symptoms. She had no family history of malignant diseases and no previous medical history. After physical examination, showing visual acuity of 3/20 in the right eye, a normal left eye and no findings from fundus examination, the patient underwent an orbital computed tomography demonstrating a right solid tissue orbital mass, measuring $11 \times 10 \times 7 \mathrm{~mm}$, invading the posterior sclera and pressing on the optic nerve (fig. 1). A fine-needle orbital biopsy aspiration revealed a low differentiated adenocarcinoma. Subsequent chest computed tomography showed an irregularly shaped pulmonary mass measuring $2 \times 1.5 \mathrm{~cm}$ in the apical section of the right inferior lobe, without lymph node involvement (fig. 2). A specimen of the lesion taken via incision biopsy confirmed the diagnosis of a low-grade lung adenocarcinoma. 
The patient was therefore diagnosed with metastatic lung adenocarcinoma (T1, N0, M1, stage IV), and was treated with combination chemotherapy consisting of docetaxel $100 \mathrm{mg} / \mathrm{m}^{2}$ plus carboplatin $(\mathrm{AUC}=5.5)$ on day 1 and bevacizumab $(7.5 \mathrm{mg} / \mathrm{kg}$ repeated every 28 days for 6 cycles) with no improvement of visual acuity and stable lung disease. After the completion of the 6th cycle, bevacizumab was continued as maintenance therapy every 21 days for 9 cycles. Palliative radiotherapy at the orbital mass (external beam 3D conformal radiotherapy, using linear accelerator, with a total dose of $30 \mathrm{~Gy}$ ) was added during maintenance therapy. A new thoracic computed tomography at the 9th maintenance cycle showed progressive disease with aggravation of the initial lung mass, a right pulmonary effusion and 3 additional lung lesions in the right lower lobe and left axillary lymph nodes enlargement. Second-line chemotherapy was initiated with gemcitabine $\left(1,250 / \mathrm{m}^{2}\right.$ body surface area, days 1 and 8$)$ and pemetrexed $\left(500 \mathrm{mg} / \mathrm{m}^{2}\right.$, day1), plus bevacizumab at the maintenance dose every 21 days for 4 cycles resulting in lung tumor reduction (from 2 to $1.4 \mathrm{~cm}$ at the longest diameter). Serial magnetic resonance imaging scans of the head performed after the completion of the second-line chemotherapy revealed partial resolution of the orbital mass and improvement of vision from $0 / 10$ to 2/10 (fig. 3 ).

It is well known that in non-small cell lung cancer adenocarcinoma epidermal growth factor receptor (EGFR) mutations could be isolated, and tyrosine kinase inhibitors (TKIs) such as Tarcevaerlotinib or Iressa-gefinitib could be given as therapy [1-3]. The histopathology report from our biopsy was negative for EGFR mutations. TKIs are an established second-line treatment for EGFR positive mutation adenocarcinoma, although there is a debate whether these 2 TKI's are equally efficient [4].

A sign of response to this treatment is the rush that occurs in the patient. It seems that positive response correlates with the intensity of the presented rush. First-line treatment with TKIs failed to be established. Nevertheless, a subgroup of treatment-naive patients could benefit from first-line treatment directly with TKIs instead of the commonly used doublets (platinum plus second agent) [5].

\section{Discussion}

Metastatic tumor is considered the most common intra-ocular malignancy, but many eye metastases go unrecognized. The most common site of ocular metastases is the highly vascular uveal tract (choroid, iris and ciliary body) - and especially the posterior portion of the choroids - with a proportion of 7:1 in relation to metastasis affecting the posterior segment of the eye, the orbit and the optic nerve [6-10]. Published reports indicate breast and lung tumors to be the commonest primary neoplasms leading to eye metastasis and metastases to the eye or orbit develop in approximately 0.7 to $12 \%$ of patients with lung cancer $[6,7,11-14]$. In our patient, the ocular symptoms were probably due to the compression of the optic nerve or shift of the eye forwards (proptosis) leading to corneal exposure damage. In our case, no extreme forward shift of the eye was observed.

Most ocular metastases are asymptomatic and this may also explain the low incidence observed $[15,16]$. Therefore, blurred vision or change in visual acuity as the initial manifestation of lung carcinoma is very rare. Another interesting finding is the timing of ocular involvement. Ocular manifestations of systemic malignancy may precede the diagnosis of cancer. Approximately $30 \%$ of the patients with orbital metastases have no history of primary cancer at the time that the ocular metastasis is detected [17]. These findings indicate that symptomatic ocular metastasis could be an early event $[6,7]$. However, occurrences of metastatic lesions in the eye suggest hematogenous spread of cancer, so the lesions are considered preterminal events that occur at the final stage of lung carcinoma, when the majority of the patients already suffers from the typical lung cancer symptoms, and the mean survival is not expected to be more than 5 to 6 months $[18,19]$. The major determinants of survival after the diagnosis of choroidal metastasis are primary tumor type and local tumor invasion at the time of diagnosis. 
Available treatment options of orbital metastasis are external beam radiotherapy, plaque radiotherapy, and newer methods like surgical resection, transpupillary thermotherapy and intravitreal chemotherapy. Systemic chemotherapy alone can also be used to treat metastatic tumors to the eye and orbit [20]. However, chemotherapy of the primary cancer alone is not recommended in this case. Additionally, anti-vascular endothelial growth factor therapy can be used to slow the progress of maculopathy and neuropathy as well as spare vision after local radiotherapy [21-23].

\section{Conclusions}

In conclusion, when an orbital lesion is discovered, the differential diagnosis should include secondary metastases due to malignant tumors originated from distal organs. This case highlights that the ocular base is a potential site of metastasis of lung cancer and the clinical doctor should be alert.

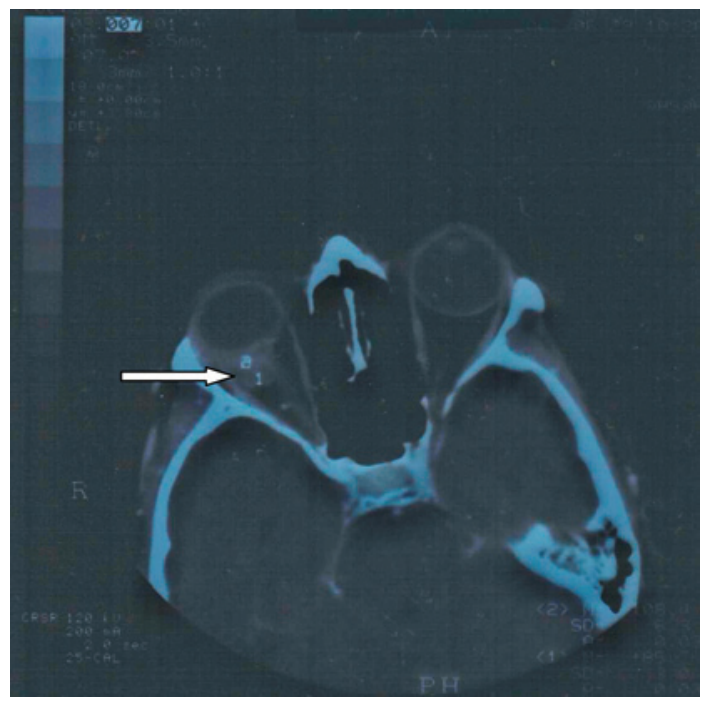

Fig. 1. CT brain scan upon admission. 


\begin{tabular}{c|l|l|l}
$\begin{array}{c}\text { Case Reports in } \\
\text { Ophthalmology }\end{array}$ & $\begin{array}{l}\text { Case Rep Ophthalmol 2011;2:34-38 } \\
\text { DOl: 10.1159/000323945 }\end{array}$ & $\begin{array}{l}\text { Published online: } \\
\text { January 21, 2011 }\end{array}$ & $\begin{array}{l}\text { O 2011 S. Karger AG, Basel } \\
\text { ISSN 1663-2699 } \\
\text { www.karger.com/cop }\end{array}$ \\
\hline
\end{tabular}

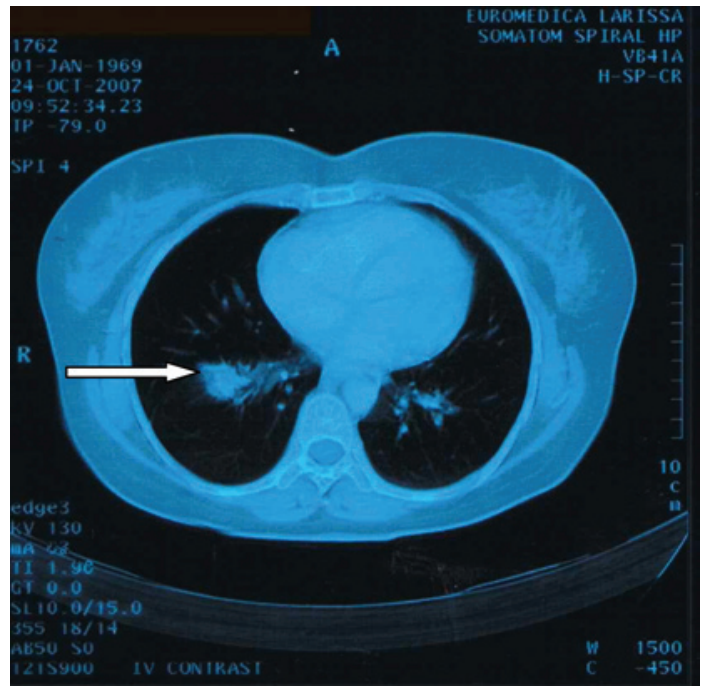

Fig. 2. CT thorax scan upon admission.

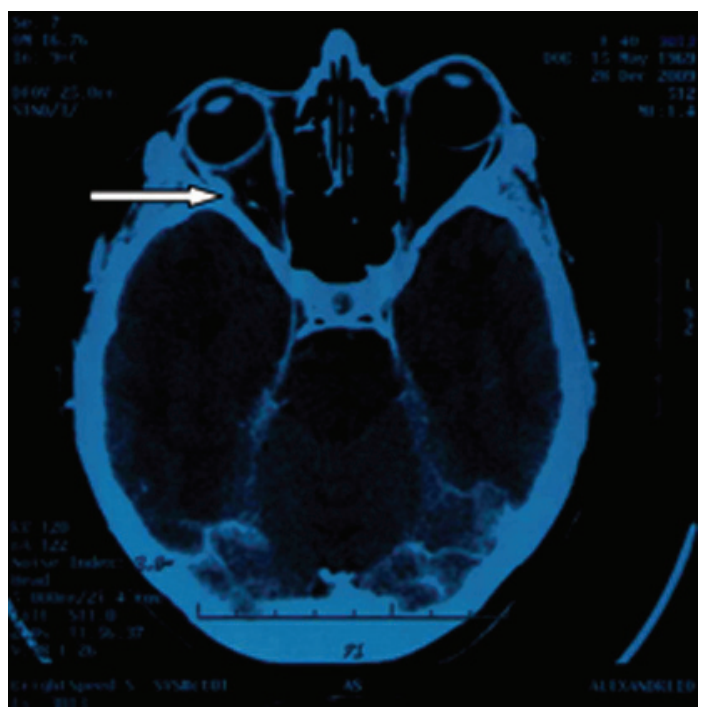

Fig. 3. Brain MRI after completion of 2nd line chemotherapy. 


\section{References}

1 Clark GM, Zborowski DM, Culbertson JL, Whitehead M, Savoie M, Seymour L, Shepherd FA: Clinical utility of epidermal growth factor receptor expression for selecting patients with advanced non-small cell lung cancer for treatment with erlotinib. J Thorac Oncol 2006;1:837-846.

-2 Wu YL, Zhong WZ, Li LY, Zhang XT, Zhang L, Zhou CC, Liu W, Jiang B, Mu XL, Lin JY, Zhou Q, Xu CR, Wang Z, Zhang GC, Mok T: Epidermal growth factor receptor mutations and their correlation with gefitinib therapy in patients with non-small cell lung cancer: a meta-analysis based on updated individual patient data from six medical centers in mainland China. J Thorac Oncol 2007;2:430-439.

-3 Roberts PJ, Stinchcombe TE, Der CJ, Socinski MA: personalized medicine in non-small-cell lung cancer: is KRAS a useful marker in selecting patients for epidermal growth factor receptor-targeted therapy? J Clin Oncol 2010;28:4769-4777.

-4 Gridelli C, Maione P, Galetta D, Colantuoni G, Del Gaizo F, Ferrara C, Guerriero C, Nicolella D, Rossi A: Three cases of long-lasting tumor control with erlotinib after progression with gefitinib in advanced non-small cell lung cancer. J Thorac Oncol 2007;2:758-761.

5 Sequist LV: First-generation epidermal growth factor receptor tyrosine kinase inhibitors in EGFR mutation: positive non-small cell lung cancer patients. J Thorac Oncol 2008;3(6 suppl 2):S143-S145.

-6 Ferry AP, Font RL: Carcinoma metastatic to the eye and orbit. I. A clinicopathologic study of 227 cases. Arch Ophthalmol 1974;92:276-286.

7 Shields CL, Shields JA, Gross NE, Schwartz GP, Lally SE: Survey of 520 eyes with uveal metastases. Ophthalmology 1997;104:1265-1276.

8 Brady LW, O’Neill EA, Farber SH: Unusual sites of metastases. Seminars Oncol 1977;4:59-64.

9 Nelson CC, Hertzberg BS, Klintworth GK: A histopathologic study of 716 unselected eyes in patients with cancer at the time of death. Am J Ophthalmol 1983;95:788-793.

10 de Potter P: Ocular manifestations of cancer. Curr Opin Ophthalmol 1998;9:100-104.

-11 Wolstencroft SJ, Hodder SC, Askill CF, Sugar AW, Jones EW, Griffiths AP: Orbital metastasis due to interval lobular carcinoma of the breast. Arch Ophthalmol 1999;117:1419-1421.

12 Bloch RS, Gartner S: The incidence of ocular metastatic carcinoma. Arch Ophthalmol 1971;85:673-675.

13 Eliassi-Rad B, Albert DM, Green WR: Frequency of ocular metastases in patients dying of cancer in eye bank populations. Br J Ophthalmol 1996;80:125-128.

14 Albert DM, Rubenstein RA, Scheie HG: Tumor metastasis to the eye. I. Incidence in 213 adult patients with generalized malignancy. Am J Ophthalmol 1967;63:723-726.

15 Jakobiec F, Rootman J, Jones I: Secondary and metastatic tumors of the orbit. Clin Opthalmol 1998;2:51-64.

16 Goldberg R, Rootman J: Clinical characteristics of metastatic orbital tumors. Ophthalmology 1990;97:620-624.

17 Velten IM, Gusek-Schneider GC, Tomandl B: Diplopia as first symptom of a bronchogenic carcinoma. Klin Monatsbl Augenheilkd 2000;217:52-54.

18 Stephens RF, Shields JA: Diagnosis and management of cancer metastatic to the uvea: a study of 70 cases. Ophthalmology 1979;86:1336-1349.

19 Freedman MI, Folk JC: Metastatic tumors to the eye and orbit. Patient survival and clinical characteristics. Arch Ophthalmol 1987;105:1215-1219.

20 Wilson MW, Czechonska G, Finger PT, Rausen A, Hooper ME, Haik BG: Chemotherapy for eye cancer. Surv Ophthalmol 2001;45:416-444.

21 Finger PT: Anti-VEGF bevacizumab $\left(\right.$ Avastin $^{\circledR}$ ) for radiation optic neuropathy. Am J Ophthalmol 2007;143:335-338

22 Finger PT: Radiation retinopathy is treatable with anti-vascular endothelial growth factor bevacizumab (Avastin). Int J Radiat Oncol Biol Phys 2008;70:974-977.

23 Finger PT, Chin K: Anti-vascular endothelial growth factor bevacizumab (Avastin) for radiation retinopathy. Arch Ophthalmol 2007;125:751-756. 